\title{
EL FERVOR MARIANO Y LA VERSATILIDAD DEL RETABLO:
}

\section{ALGUNOS EJEMPLOS PARROQUIALES DE JEREZ DE LA FRONTERA}

\author{
PABLO J. POMAR RODIL \\ UNIVERSIDAD DE SEVILLA
}

RESUMEN: La consolidación durante la Edad Moderna de la creencia teológica católica respecto a la concepción inmaculada de la Virgen María, propició un clima de fervor que tuvo un notable reflejo en toda la cultura española y particularmente en las artes plásticas. En el presente artículo se analiza el impacto que tales ideas ejercieron en las capillas mayores de la colegiata y parroquias de Jerez de la Frontera, tanto en la reforma de los retablos preexistentes como en el diseño de los que se levantaron de nueva planta.

PALABRAS CLAVE: Retablo, Capilla mayor, Inmaculada concepción, Iglesia parroquial, Jerez de la Frontera.

\section{MARIAN FERVOUR AND THE VERSATILITY OF THE ALTARPIECE: SOME PARISH EXAMPLES OF JEREZ DE LA FRONTERA}

\begin{abstract}
The consolidation during the Modern Age of the Catholic theological belief regarding the immaculate conception of the Virgin Mary, led to an atmosphere of fervor that had a remarkable reflection in all Spanish culture and particularly in the plastic arts. This article analyzes the impact that such ideas exerted on the main chapels of the collegiate church and parishes of Jerez de la Frontera, both in the reform of the pre-existing altarpieces and in the design of the new ones.
\end{abstract}

KEYWORDS: Altarpiece, Main Chapel, Immaculate Conception, Parish Church, Jerez de la Frontera. 
Consecuencia visible del apasionado clima de fervor inmaculista, y en general mariano, vivido en España durante el siglo XVII serán las reformas que a partir de entonces fueron sufriendo los retablos mayores de muchas de sus iglesias, y que alcanzaron a modificar su principal referencia visual con la introducción en su calle central de hornacinas, e incluso amplios camarines, destinados a albergar imágenes de la Virgen María. Cabe pensar que el ardoroso ambiente que propició estas transformaciones comenzase en torno a 1645, año en que Felipe IV obtuvo del papa Inocencio X la bula In his per quae Beatissimae Virginis, que permitía el mantenimiento de la fiesta de la Inmaculada «in Regnis Hispaniarum tantum» a pesar de la supresión de 1642 por parte de Urbano VIII ${ }^{1}$. Las iglesias de la archidiócesis de Sevilla no permanecerían ajenas a este proceso, que con cierta frecuencia vendría motivado por la revitalización de la devoción y el culto a antiguas imágenes de la Virgen de origen medieval², de lo que existen ejemplos significativos en Jerez de la Frontera, tanto en templos seculares como de regulares, si bien nos ceñiremos en este trabajo al estudio de los primeros ${ }^{3}$.

En Jerez, la decisión de Paulo V de imponer silencio en septiembre de 1617 a los defensores de la tesis maculista predispuso a la Ciudad a la inmediata adopción de un voto a favor de la entonces denominada «piadosa creencia», según la cual Dios Padre habría preservado a la Virgen María del pecado original, declaración que pronto suscribirían en España más cabildos seculares y eclesiásticos, universidades, cofradías y otras muchas instituciones ${ }^{4}$. Esta sucesión de reacciones locales a los distintos hitos que jalonarían el lento desarrollo teológico que concluiría con la proclamación del dogma, ya en el siglo XIX, podría seguirse, con mayor o menor detalle, en las fiestas y procesiones celebradas, capillas votivas o monumentos efímeros levantados y en un muy variado modo de expresiones plásticas de

\footnotetext{
${ }^{1}$ STRATTON, Suzanne: «La Inmaculada Concepción en el arte español», Cuadernos de arte e iconografía, 2 (1988), pp. 3-128.

2 Sobre el origen de la devoción a la Virgen María en Jerez, que se remonta a tiempos de la Reconquista, vid. SANCHO DE SOPRANIS, Hipólito: Historia social de Jerez de la Frontera al fin de la Edad Media, Jerez de la Frontera, CEHJ, 1959, t. II, pp. 103-115; SANCHO DE SOPRANIS, Hipólito: Mariología medieval xericiense, Jerez de la Frontera, Centro de Estudios Históricos Jerezanos, 1973; SANCHO DE SOPRANIS, Hipólito: La Capilla Capitular de La Concepción de la iglesia del Convento de San Francisco el Real de Jerez de la Frontera. 1539-1777, Jerez de la Frontera, Centro de Estudios Históricos Jerezanos, 1960; JIMÉNEZ LÓPEZ DE EGUILETA, Javier E.: «Devociones marianas en Jerez y su comarca durante los primeros tiempos de la conquista cristiana», Asidonense, 10 (2016), pp. 55-83.

${ }^{3}$ En el ámbito monástico jerezano ya nos ocupamos tangencialmente sobre estos procesos de transformación de los programas iconográficos de los retablos en función de la devoción a una imagen de la Virgen en POMAR RODIL, Pablo J., «Hacia una historia del Retablo Mayor de la Cartuja de la Defensión en el siglo XVIII», en Actas del congreso internacional sobre las cartujas valencianas. El Puig, Universidad de Salzburgo, 2004, pp. 79-84.

${ }^{4}$ MESA GINETE, Francisco de: Historia Sagrada y Politica de la Muy Noble y Muy Leal Ciudad de Tarteso, Turdeto, Asta Regia, Asido Cesariana, Asidonia, Gera, Jerez Sidonia, hoy Jerez de la Frontera [1754], Jerez de la Frontera, Melchor García Ruiz, 1888, t. II, p. 484.
} 
las que serían factoras las distintas instituciones antes enunciadas ${ }^{5}$. Como ya señalamos, en los templos que nos ocupan en este trabajo -que suponen una muestra de lo que podría ser un estudio mucho más amplio- este fervor mariano encuentra su reflejo material en las transformaciones sufridas por sus retablos mayores, ejerciendo una considerable labor como modelo de aquellas la colegiata de San Salvador, espejo litúrgico en el que se miraban el resto de parroquias, que piadosamente trataban de emularla ${ }^{6}$.

En la colegiata jerezana, a mediados del siglo XVII, por el deseo de hacer ostensible la adhesión del cabildo a las tesis inmaculistas, se alteró el programa iconográfico de su altar mayor con la inclusión de una imagen de la Purísima (imagen 1) propiedad del canónigo magistral don Alonso Caballero de los Olivos, celoso concepcionista ${ }^{7}$. La escultura fue además dotada entonces de un marco apropiado, incorporando al retablo lo que la documentación define como un «tabernáculo de columnas todo dorado», que fue costeado igualmente por el propio magistral ${ }^{8}$. Conocemos también que en el cabildo de veintiocho de marzo de 1662 se anota un pago a Diego Montero «por los velos que está haciendo para la imagen de Nuestra Señora que está en el Altar Mayon». Éstos, dado que la imagen, que se conserva, es de talla, suponemos que harían referencia a alguna suerte de postizo o aditamento vestimentario, acaso un manto, y supone un significativo precedente de cuanto veremos en otras parroquias de la ciudad. Conviene destacar también, como prueba de la importancia del culto inmaculista, cuya centralidad el cabildo quiso mantener a toda costa pese a las incomodidades espaciales padecidas durante el siglo XVIII a raíz de las obras de construcción del nuevo templo, cómo la mencionada imagen fue la escogida-como sabemos por el testimonio del visitador Juan Bejarano Muñoz en 1705- para presidir el altar

\footnotetext{
${ }^{5}$ De la extensísima bibliografía existente sobre la creencia inmaculista en España nos permitimos seleccionar, por su estrecha vinculación a los temas tratados en el presente estudio, los títulos siguientes: LABARGA GARCÍA, Fermín: «El posicionamiento inmaculista de las cofradías españolas», Anuario de historia de la Iglesia, 13 (2004), pp. 23-44; CAMPOS Y FERNÁNDEZ DE SEVILLA, Francisco Javier (coord.): Actas del simposium La Inmaculada Concepción en España. Religiosidad, historia y arte, San Lorenzo de El Escorial, Ediciones Escurialenses, 2005.

${ }^{6}$ Sobre el concepto de emulación piadosa vid. GÓMEZ PIÑOL, Emilio: «La "forma nueva" de adornar los templos sevillanos del siglo XVII y la emulación piadosa. El retablo mayor del hospital de la Caridad», en D. Sánchez-Mesa Martínez y J. J. López Guadalupe (coords.): Diálogos de arte. Homenaje al profesor Domingo SánchezMesa Martín, Granada, Universidad de Granada, 2014, pp. 223-246, particularmente de la 226 a la 228, y POMAR RODIL, Pablo J.: «La santa emulación. La elevación a catedral de la colegiata del Salvador», XX siglos, 54 (2005), pp. 54-63.

${ }^{7}$ Los límites cronológicos en que nos movemos con seguridad van de 1634, año de la visita canónica transcrita por Repetto, donde no se cita Inmaculada alguna, hasta 1652, cuando el magistral Caballero de los Olivos la dona al Cabildo, mas quedando constancia en el documento de entrega de la imagen de que por aquel entonces ya llevaba tiempo en el altar mayor. REPETTO BETES, José Luis: Historia del Cabildo Colegial de Jerez de la Frontera. 1264-1984, Jerez de la Frontera, Caja de Ahorros de Jerez, 1986, pp. 514-515.

${ }^{8}$ Archivo Histórico Diocesano de Jerez de la Frontera (En adelante AHDJF), Fondo Hispalense, Serie Jerez de la Frontera, Sección Ordinario, caja 14, doc. 13.

9 AHDJF. Fondo Colegial, Sección I, Caja 1, Actas Capitulares, Libro II (1660-1700), f. 10r.
} 
provisional donde, con patentes penalidades, subsistía el culto capitular, pese a que en la precariedad de aquel espacio no existía retablo alguno y apenas tenía por adorno unos cuadros procedentes de antiguo edificio ${ }^{10}$.

\section{Imagen 1}

\section{Inmaculada Concepción. Catedral de Jerez, 1650 ca.}

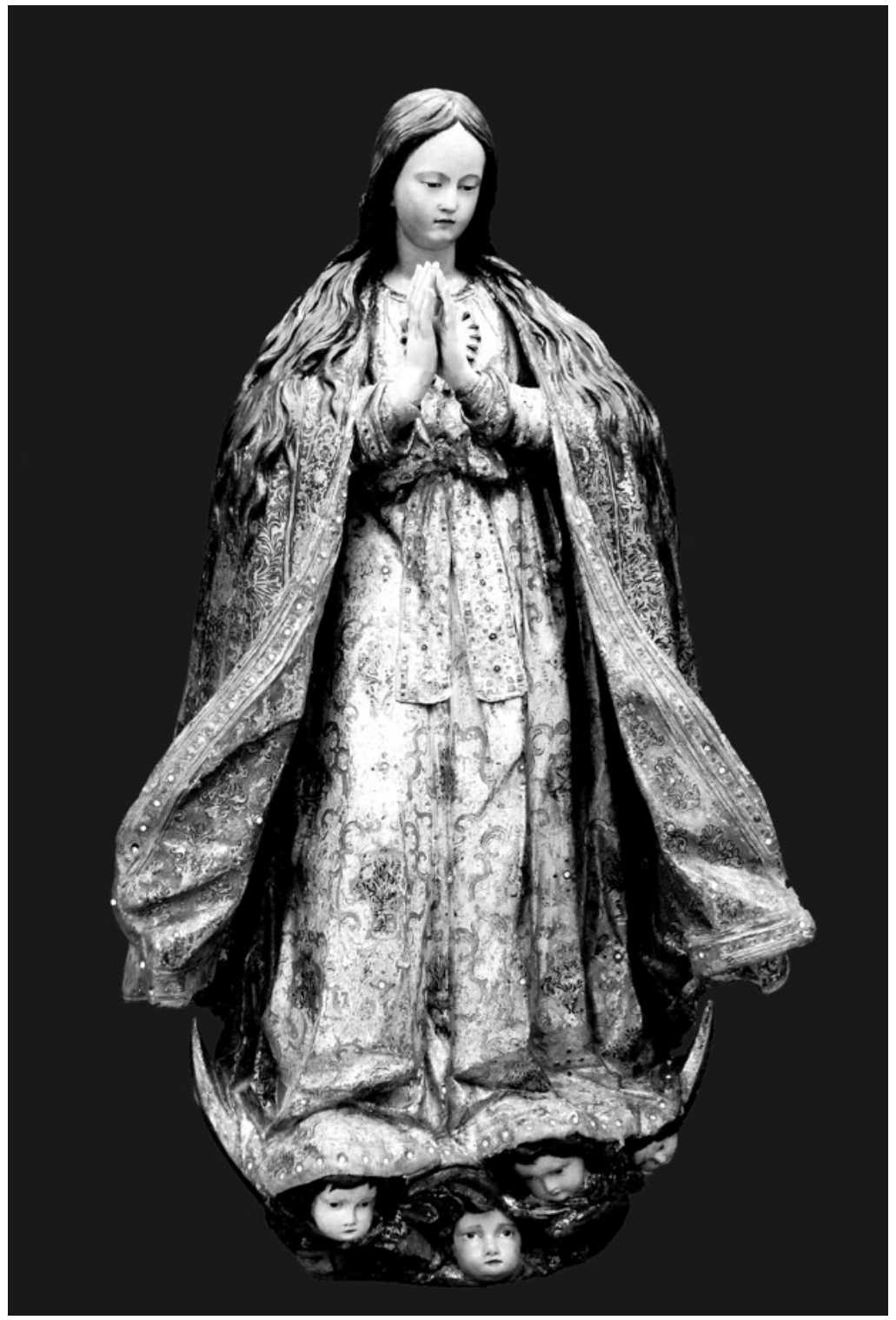

Fotografía Manuel Cobo

\footnotetext{
10 «La yglesia en que de presente asisten a hazer sus oficios los canónigos es una nave de tres que demuestra haver tenido esta collexial porque la principal y la que mira al poniente están caídas y arruinadas y solo permanece la que está al oriente que es angosta y muy estrecha y con poca luz. El altar mayor no tiene retablo y lo adornan unos quadros de pintura que estavan en el altar maior viejo y en lo principal del altar está colocada una imagen de nuestra señora de la concepzión de cuerpo entero de talla bestida». Resulta y mandatos de la visita pastoral realizada por don Juan Bejarano Muñoz a las parroquias de Jerez de la Frontera. Mayo-julio de 1705. Archivo General del Arzobispado de Sevilla (En adelante AGAS). Sección II, Serie visitas, legajo 1348, s/f.
} 
En la parroquia de San Dionisio consta la existencia de una antigua imagen de la Virgen cuya devoción fue recuperada y renovada por el clero parroquial a mediados del siglo XVII. Su incorporación en medio del retablo pictórico que entonces presidía el templo no debió de significar una alteración sustancial del programa narrativo original, suponiendo más bien una suerte de actualización iconográfica ${ }^{11}$. El historiador fray Esteban Rallón, que escribió su Historia de Jerez hacia 1665, lo resumió de este modo: «En esta iglesia se venera una imagen antigua con advocación de Nuestra Señora del Olmo, cuya memoria estaba perdida hasta que en estos tiempos se volvió a resucitar por el cuidado de sus beneficiados: volviéronla a renovar porque estaba muy deslucida. Pusiéronla en el altar mayor, y se le hizo una solemnísima fiesta con octava» ${ }^{12}$. De la descripción acaso podría deducirse que la imagen se hubiese llevado al altar mayor sólo para esas celebraciones litúrgicas, sin embargo, parece más probable que éstas se organizasen para conmemorar su nueva y central ubicación. Es significativo al respecto que el licenciado Juan Bejarano Muñoz, en la ya mencionada visita pastoral de 1705, señalase que el retablo mayor estaba entonces presidido por una imagen de talla de la Virgen de Loreto $^{13}$. Al margen del cambio de título mariano, que no podemos saber

11 Del retablo de San Dionisio, que se conservó hasta 1770, y cuyas tablas pictóricas permanecieron posteriormente almacenadas en la cámara baja de la torre de la Atalaya hasta su desaparición en el siglo XX, se conocen sus principales datos relativos a datación y autoría. Fue concertado con Juan de Oviedo y de la Bandera en 1593, a quien en el documento contractual suscrito se le exigía que el retablo, que había de ejecutarse de pino, borne y castaño, alcanzase los casi doce metros de altura por poco más de siete de anchura «acomodando los tableros y pieças de un retablo viejo que estaba hecho [...] y que la obra añadida vaya enriquesida de talla». Estos tableros que Oviedo había de reaprovechar acaso puedan ponerse en relación con la figura de Diego de Tiedra, quien en 1569 había dado poder para cobrar de la fábrica de San Dionisio unos trabajos hechos con anterioridad. Finalmente, el retablo fue traspasado por el maestro a su hermano Martín de Oviedo, quien lo completó al año siguiente. En su dorado y policromía intervinieron en 1597 y 1598 Francisco Cid y al año siguiente Diego de Campos que desistió de la obra y la traspasó a Diego de Acedo, que la concluiría en 1600. Sobre la apariencia del retablo y los temas que se representaban en el mismo, las fuentes son coincidentes. Así, en el esbozo iconográfico inserto en el contrato de Diego de Campos se especifica que el altar estaba compuesto «de la vida y martirio del dicho santo [san Dionisio] con sus ornatos e istorias»; Fray Esteban Rallón señalará en torno a 1660 que «el retablo del altar mayor es de pincel, de lo bueno que hoy se halla en España. En sus cuadros está historiado el martirio de nuestro gran padre y patrono San Dionís, con sus guarniciones doradas y estofadas». Por último, redunda sobre lo mismo la sucinta descripción del visitador Gonzalo de Mier de 1673, que señala que «el altar mayor es de pintura, historiada la vida de san Dionisio, con molduras gruesas doradas bien compuesto y adornado que suben hasta arriba». LÓPEZ MARTÍNEZ, Celestino: Desde Jerónimo Hernández. hasta Martínez Montañés, Sevilla, Rodríguez, Giménez y Compañía, 1929, pp. 73, 88 y 167; LÓPEZ MARTÍNEZ, Celestino: Desde Martínez. Montañés hasta Pedro Roldán, Sevilla, Rodríguez, Giménez y Compañía, 1932, pp. 169 y 177; ANTÓN PORTILLO, Jesús y JÁCOME GONZÁLEZ, José: «Apuntes histórico-artísticos de Jerez de la Frontera en los siglos XVI-XVIII (3 ${ }^{a}$ serie)», Revista de Historia de Jerez, 8 (2002), p. 123; LÓPEZ MARTÍNEZ, Celestino: Retablos y esculturas de traza sevillana, Sevilla, Rodríguez, Giménez y Compañía, 1928, p. 6; RALLÓN, Fray Esteban: Historia de la ciudad de Xerez de la Frontera y de los reyes que la dominaron desde su primera fundación [1665 ca.], Jerez de la Frontera, Universidad de Cádiz, 2003, t. IV, p. 136; Visita de las parroquias y de las demás iglesias que tocan a la jurisdicción eclesiástica de la ciudad de Xerez de la Frontera, que hizo el licenciado don Gonzalo de Mier y Barreda, visitador general de este arzobispado. Noviembre-diciembre 1673. AGAS, Sección II, visitas, legajo 1443, s./f.

12 RALLÓN, Fray Esteban: Historia de la ciudad... op. cit., 2003, t. IV, p. 137.

13 «Es esta yglesia de tres naves y en la principal lo que hace el altar maior y presbiterio es de bóveda de cantería y lo demás de la yglesia está cubierto de maderas y texado. El altar mayor tiene retablo de escultura dorado y lienzo de pintura y en la principal parte del esta dicha ymagen de Nuestra Señora de Cuerpo entero de talla con el título de Loreto». Resulta y mandatos... op. cit., 1705. AGAS, Sección II, Serie visitas, legajo 1348, ff. 24r-28r. 
si se debe a un error de Rallón, de Bejarano o a que efectivamente la imagen hubiese cambiado de advocación o incluso fuese otra distinta, el caso es que podemos confirmar que el viejo retablo pictórico fue reformado con la intención de entronizar en el lugar más destacado de la iglesia a una imagen de la Virgen María.

En otros casos, podemos intuir que el deseo de inserción en el altar mayor, y en ubicación preferente, de una imagen de Nuestra Señora pudo contribuir a la completa sustitución del retablo y hasta la transformación en lo decorativo de toda la cabecera. Al respecto conviene tener en cuenta que, en el siglo XVII, el célebre historiador y beneficiado de la parroquia de San Lucas, don Gonzalo de Padilla, logró revivir entre su feligresía la devoción a la Virgen de Guadalupe, que, pese a su áulico origen medieval vinculado a Alfonso XI y a la Reconquista, había llegado casi a extinguirse ${ }^{14}$. Cabe pensar, por tanto, que fuese precisamente este renovado ardor mariano el que en 1665 moviese a reemplazar el preexistente retablo por otro que realizó Lorenzo de Vargas ${ }^{15}$, que de manera elocuente contó desde su inicio con la imagen de la Virgen de Guadalupe en su nicho principal, mientras que la obligada presencia del titular del templo se resolvía con un lienzo que lo representaba en el ático, como consta de las descripciones de los visitadores Gonzalo de Mier $^{16}$, en 1673, y Juan Bejarano ${ }^{17}$, en 1705.

A pesar de la destacada ubicación central de la hornacina que ocupaba la Virgen, su angostura dificultaba la adopción de los nuevos gustos en el vestido de imágenes marianas

\footnotetext{
${ }^{14}$ RALLÓN, Fray Esteban: Historia de la ciudad... op. cit., t. IV, p. 132; POMAR RODIL, Pablo J.: «Nuestra Señora de Guadalupe», en J. E. Jiménez López de Eguileta y P. J. Pomar Rodil (coords.): Limes Fidei. 750 años de Cristianismo en Jerez, Jerez de la Frontera, Diócesis de Asidonia-Jerez, 2014, pp. 208-209; POMAR RODIL, Pablo J.: «Milagro del esclavo moro», en J. E. Jiménez López de Eguileta y P. J. Pomar Rodil (coords.): Limes Fidei. 750 años de Cristianismo en Jerez, Jerez de la Frontera, Diócesis de Asidonia-Jerez, 2014, pp. 210-211; SAN JOSÉ, Fray Francisco de: Historia universal de la primitiva y milagrosa imagen de Nuestra Señora de Guadalupe, fundación, y grandezas de su santa casa, y algunos de los milagros que ba hecho en este presente siglo, Madrid, Antonio Marín, 1743, pp. 131-134. 15 BARROSO VÁZQUEZ, María Dolores: «Arquitectura efímera en el Jerez del Seiscientos: Antón Martín Calafate y Lorenzo de Vargas», Trivium, 5 (1993), p. 372; También fue Lorenzo de Vargas quien poco después, en 1677, por compromiso con el caballero Agustín José Ramírez de Zurita, quedase encargado de confeccionar unas andas para la imagen, que quizá fuesen las que todavía se mencionan en inventarios de finales del siglo XIX. Todo ello pone de relieve la extraordinaria pujanza de la devoción, que traspasaba los límites del templo parroquial desarrollando culto externo por las calles de la feligresía que se mantuvo en el tiempo. ANTÓN PORTILLO, Jesús y JÁCOME GONZÁLEZ, José: «Apuntes histórico-artísticos... op. cit., 2002, p. 125; Inventario de la Iglesia parroquial y real del evangelista señor San Lucas realizado por don José María Arcila Navarro, 1886. AGAS, Sección IV, Serie 13, legajo 691, s/f.

16 «Y el sagrario-custodia de dicho altar mayor es muy costoso, de diferentes columnas de madera doradas y encima está un nicho con una imagen de Nuestra Señora de Guadalupe, y lo demás del altar mayor es de diferentes pinturas con sus marcos dorados es obra nueva que se hizo el año de 1666, y en lo alto está la imagen de san Lucas, titular de esta iglesia». Visita de las parroquias... op. cit., 1673. AGAS, Sección II, visitas, legajo 1443, s./f.

17 «El altar maior tiene retablo de escultura dorado en cuio principal nicho está colocado una ymagen de nuestra señora de cuerpo entero bestida adbocazión de Guadalupe y más arriba la ymagen de San Lucas pintada en lienzo». Resulta y mandatos... op. cit., 1705. AGAS, Sección II, Serie visitas, legajo 1348, s./f.
} 
que, como vimos en la colegiata, se popularizaba en aquellos años, de ahí que en 1715 haya ya noticias que revelan la intención de transformar aquel ajustado nicho en un desahogado camarín $^{18}$. Todo este proceso conllevó incluso labores de actualización decorativa en los muros y bóvedas de la muy antigua cabecera gótica del templo, que significativamente fue adornada con simbología eminentemente mariana. Estos trabajos quizá puedan relacionarse con la figura de Pedro Mateos de Ledesma, que tuvo a su cargo el estofado y dorado del retablo en $1665^{19}$. En cualquier caso, esa bóveda y las paredes de la capilla mayor serían nuevamente decoradas en 1723, como paso previo a la renovación de toda la cabecera, que tendría su ápice en el nuevo retablo levantado por Francisco López ${ }^{20}$. En éste, la Virgen de Guadalupe permaneció como su elemento devocional visualmente más destacado, al continuar ocupando el camarín central (imágenes 2 y 3), ubicado bajo el relieve del evangelista titular del templo, lo que sin duda está relacionado, no sólo con la disposición de la imagen en el retablo precedente, sino también con el hecho de que fuese la propia cofradía de Guadalupe quien encargase y sufragase la obra ${ }^{21}$. De hecho, la intensa transformación sufrida por el templo durante la primera mitad del siglo XVIII se ha llegado a considerar en sentido lato como consecuencia de este renovado fervor mariano ${ }^{22}$.

\footnotetext{
18 «Y que el asiento de berdugado de Nuestra Señora de Guadalupe que está en el altar maior, con la mitad descubierto fuera del nicho con indezencia se cubra con un belo de razo o tafetán recoxiéndolo plegado que remate en figura piramidal ynterin que no se hase el camarín que se dispone haser para que dicha ymagen este con la devida dezencia». Resulta y mandatos de la visita pastoral realizada por don Pedro Fernández Zurita a las parroquias de Jerez de la Frontera. Octubre 1715-enero 1716. AGAS, Sección II, Serie visitas, legajo 1359. f. 228 r.

19 ANTÓN PORTILLO, Jesús y JÁCOME GONZÁLEZ, José: «Apuntes histórico-artísticos... op. cit., 2002, p. 127.

${ }^{20}$ ALONSO DE LA SIERRA FERNÁNDEZ, Lorenzo y HERRERA GARCÍA, Francisco Javier: «Francisco López y la difusión del barroco estípite el retablo bajo-andaluz», Archivo hispalense, 230 (1992), pp. 145-146; MORENO ARANA, José Manuel: «La transformación barroca de la iglesia de San Lucas de Jerez en el siglo XVIII», en F. Aroca Vicenti y F. Pérez Mulet (coords.): Nuevas aportaciones a la Historia del Arte en Jerez de la Frontera y su entorno, Cádiz, Universidad de Cádiz, 2016, p. 114.

21 «Que por quanto estamos ynformados que los hermanos de la cofradía de nuestra Señora de Guadalupe quieren dorar el retablo de el altar maior exforsándose à executarlo el cura de esta Yglesia solicitara algunas limosnas para este efecto entre sus parroquianos y habiendo junto alguna cantidad nos dará quenta para que se pueda principiar remitiéndonos tanteo del estado en que se halla la fábrica para que mediante su pobresa podamos aplicar se sus rentas aquella porción que nos pareciere proporsionada sin hazer falta a las obligaziones más presisas». Mandatos de la visita pastoral realizada por el excmo. Arzobispo don Luis de Salcedo y Azcona a las parroquias de Jerez de la Frontera. 1728. AGAS, Sección II, Serie visitas, legajo 1369, f. 314 r.

22 Fray Francisco de San José, historiador de la Virgen de Guadalupe, tras señalar algunos de los más celebres milagros atribuidos por intercesión de su simulacro jerezano, añade que «con estas obras tan dignas del mayor aprecio en los mortales fomenta la Princesa de la Gloria la grande devoción que le tienen los Ciudadanos empeñándose en adornar su Templo con riquísimas alhajas y restaurarle de la injuria de cinco siglos que le tenía muy deteriorado y para esto se consumieron desde el año mil setecientos y catorce hasta el de mil setecientos y treinta y dos quatrocientos mil reales aviendo sido quasi toda esta cuantiosa suma de limosnas que se ofrecían à la Santa Imagen de nuestra Señora de Guadalupe teniendo solas ciento y diez casas la Parrochia y muy pobres los más de sus vecinos Oy es el Templo que tiene esta Ciudad primoroso. A él concurren los Parrochianos y devotos todas las noches à rezar el Santísimo Rosario de la siempre Virgen María allanando la devoción que profesan à la milagrosa Imagen los tropiezos que para impedirles esta obra de piedad oponen ordinariamente domésticos cuidados». SAN JOSÉ, Fray Francisco de: Historia universal... op. cit., p. 133.
} 


\section{Imagen 2}

Retablo mayor de San Lucas. Francisco López, 1723

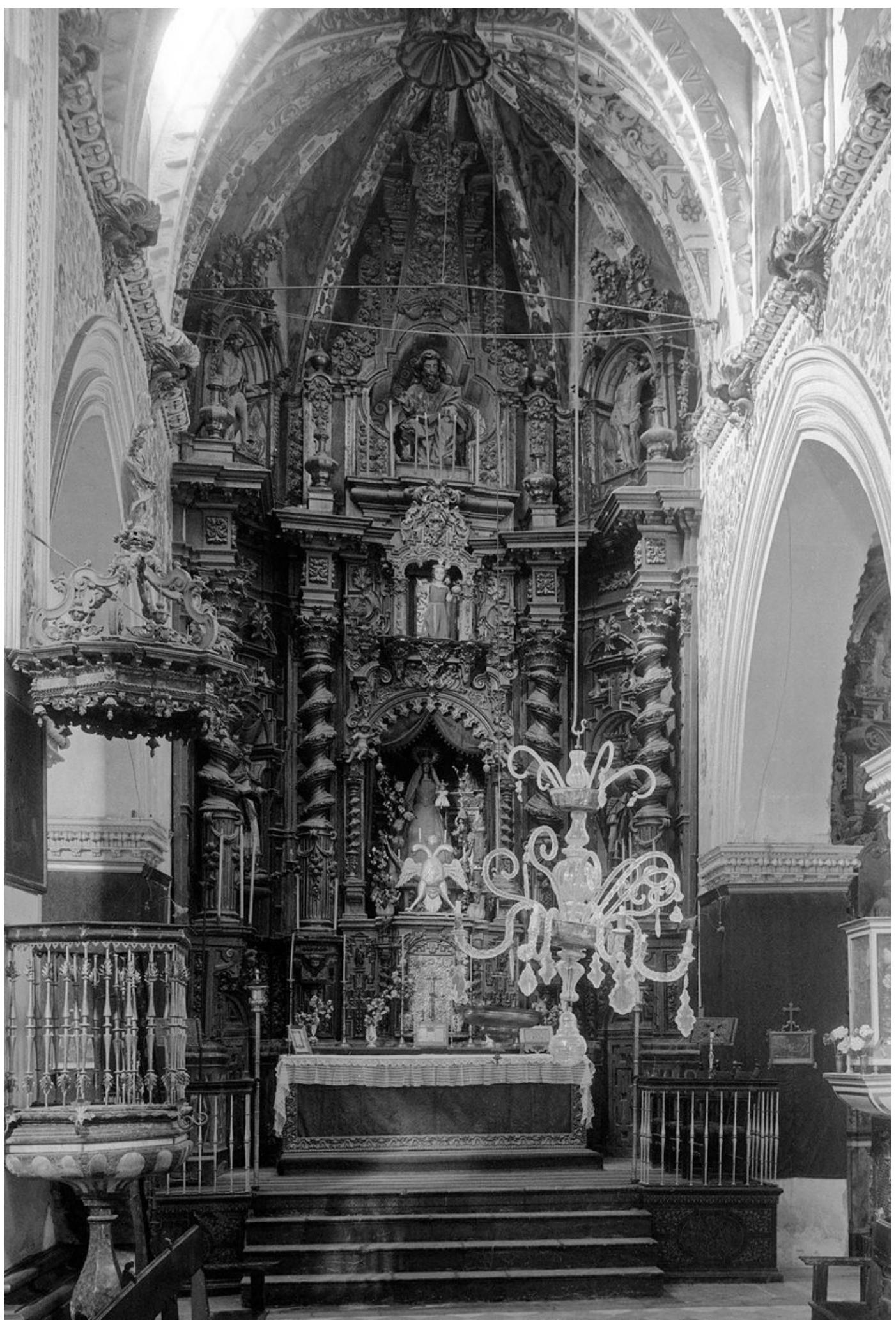

Fotografía Archivo Mas 


\section{Imagen 3}

Virgen de Guadalupe en su camarín del retablo mayor de San Lucas

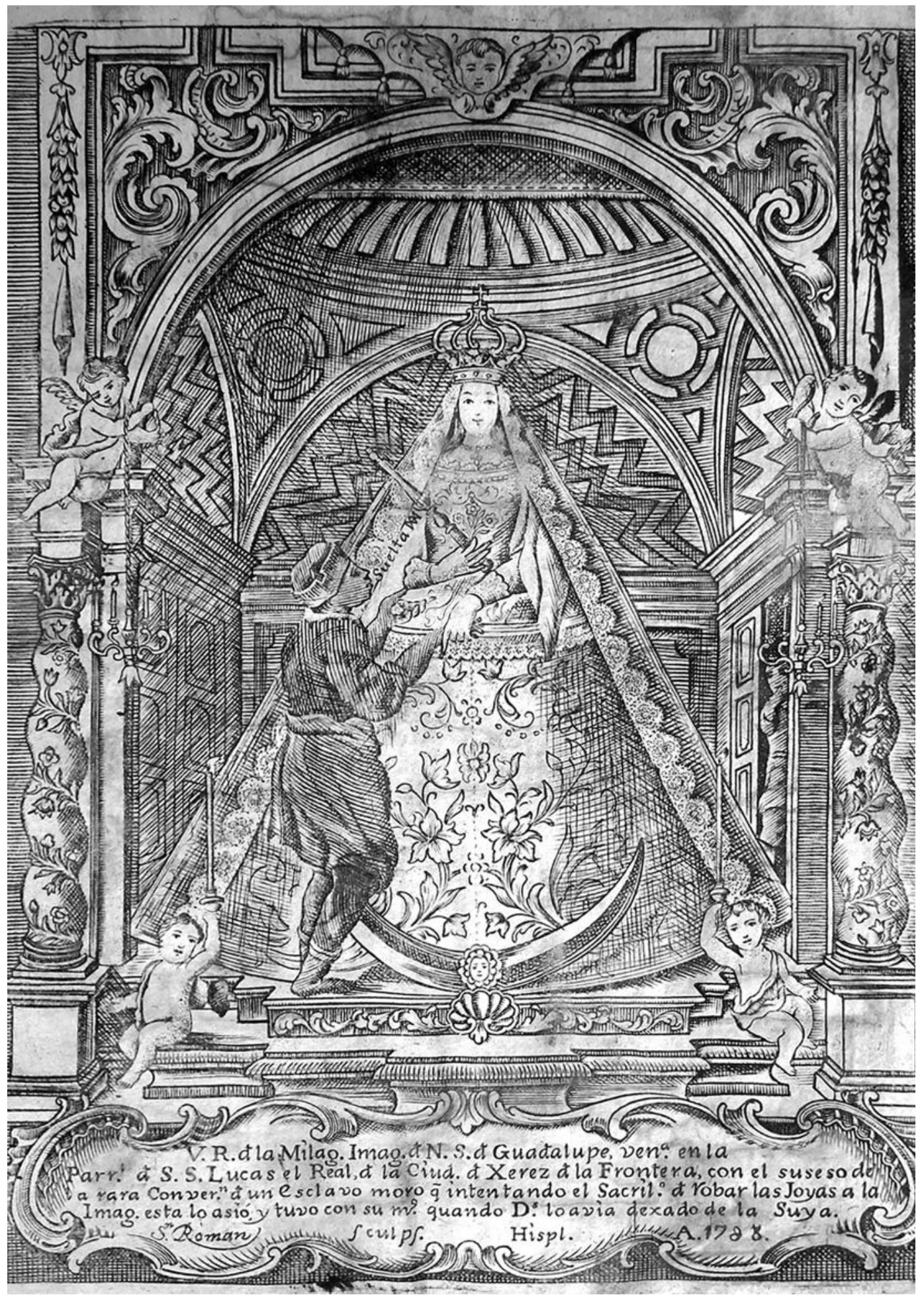

Grabado de José de San Román, 1768. 
En la vecina parroquia de San Juan encontramos un caso que guarda notables semejanzas con lo visto en San Lucas. La iconografía del retablo mayor ya incluía en posición central la Asunción, episodio de la vida de la Virgen de larga tradición en el arzobispado de Sevilla, de cuya catedral era la advocación titular. Sin embargo, se trataba de una representación narrativa que no venía motivada por fines meramente devocionales ${ }^{23}$. De otra parte, el padre Rallón menciona cómo, ya desde mediados del siglo XVII, la antigua imagen de Nuestra Señora de la Paz, obra de Nicolás de León del segundo cuarto del siglo precedente, que presidía un altar ubicado junto al púlpito, era objeto de veneración por parte de unos fieles que se habían ocupado de restaurarla y que le organizaban cultos en su honor en el mes de mayo, con fiesta y octava ${ }^{24}$. Así, cuando en 1698 se decidió sustituir el antiguo retablo mayor por uno nuevo, la fábrica aprovechó la pujanza del culto a esta imagen de la Virgen de la Paz, que también contaba con su propia cofradía a la que pertenecía buena parte de la nobleza de la collación, para que la renovación fuese viable, siendo de hecho los hermanos de Nuestra Señora de la Paz, y no la parroquia, quienes encargaron la obra al retablista sevillano Francisco Antonio de Soto ${ }^{25}$. Sin embargo, para su conclusión fue necesario el

${ }^{23}$ Del antiguo retablo de la parroquia de San Juan de los Caballeros, que fue desmontado en 1698, se conocía que había sido realizado por el pintor sevillano Alejo Fernández, dado que en 1520 había dado poder a Juan de Huejar para cobrar su labor de pintura en el mismo del mayordomo de fábrica de la parroquia, poder que debió renovar tres años más tarde, lo que indica que la fábrica no respondió al anterior requerimiento, al menos en su totalidad. La profesora Marchena Hidalgo ha especulado con que tres tablas formando un tríptico facticio de la colección particular que doña Genoveva de Hoyos y Martínez de Irujo conserva en su residencia jerezana pudiese guardar relación con esta obra, sin embargo, reconocía no poder ir más allá de la mera especulación al desconocer los temas representados por Fernández en el retablo de San Juan. El tríptico, que fue expuesto en 1929 en la Exposición Mariana que tuvo lugar en la colegiata sevillana de San Salvador, está presidido por la Asunción de la Virgen y dos parejas de santos, san Juan Bautista y san Juan Evangelista, de una parte, y san Francisco de Asís y San Antonio de Padua. La breve descripción que el licenciado Gonzalo de Mier y Barreda dejó del retablo mayor de San Juan de los Caballeros en la resulta de visita de 1673, pese a su sintetismo, nos permite seguir considerando esta procedencia, dado que el retablo de San Juan lo refiere entonces como compuesto de distintas pinturas antiguas entre las que además de los dos santos juanes, estaría representada la Asunción de la Virgen en el ático: «Y el retablo del altar mayor es de pinturas diferentes antiguas, y en él están san Juan Baptista y el Evangelista, y este es el titular, y en el remate Nuestra Señora de la Asunción, de arquitectura cuerpo entero». MARCHENA HIDALGO, Rosario: «Recuperación de una obra de Alejo Fernández», Laboratorio de Arte, 17 (2004), p. 122; GESTOSO Y PÉREZ, José: Ensayo de un diccionario de los artifices que florecieron en Sevilla desde el siglo XIII al XVIII inclusive, Sevilla, La Andalucía Moderna, 1908, t. III, p. 314; Visita de las parroquias... op. cit., 1673. AGAS, Sección II, visitas, legajo 1443, s./f.

${ }^{24}$ «y en saliendo al cuerpo de la iglesia está el altar de Nuestra Señora de la Paz, donde se venera una santa imagen antigua a quien la piedad de los fieles ha renovado, y está con mucha veneración y se le hace la fiesta por el mes de mayo con su octava» (RALLÓN, Fray Esteban: Historia de la ciudad... op. cit., t. IV, p. 133). La ubicación junto al púlpito es mencionada en el contrato de ejecución de otro retablo de la ciudad, el de la capilla de Ntra. Sra. de los Remedios, al que debía servir de modelo: «a de ser de la obra y manera del Retablo que está en la yglesia de san juan de los cavalleros de esta dicha çibdad de xeres del que está en la dicha yglesia par del púlpito de ella» (ROMERO BEJARANO, Manuel: «El escultor Nicolás de León en Jerez (II)», Diario de Jerez, 25-3-2013). El canónigo Mesa Ginete apunta un origen anterior de la advocación, de hacia 1463 y relacionada con la junta de notables que el Duque de Medina Sidonia habría llevado a cabo en el templo (MESA GINETE, Francisco de: Historia Sagrada... op. cit., t. II, p. 145).

25 ANTÓN PORTILLO, Jesús y JÁCOME GONZÁLEZ, José: «Apuntes histórico-artísticos de Jerez de la Frontera en los siglos XVI-XVIII (2 $2^{\mathrm{a}}$ serie)», Revista de Historia de Jerez, 7 (2001), p. 116; MORENO ARANA, José Manuel: El retablo en Jerez de la Frontera durante el siglo XVIII, Sevilla, Universidad de Sevilla, 2014, p. 216. 
concurso de otras fuentes de financiación, como se percibe de la petición en 1715 elevada por los cofrades al cardenal Arias, para que la fábrica contribuyese con doscientos ducados, que no sabemos si fue atendida ${ }^{26}$. Sea como fuere, en 1728 el arzobispo don Luis de Salcedo y Azcona dispuso que en los pagos contribuyese también la fábrica parroquial y que al mismo tiempo se solicitase la limosna de los feligreses ${ }^{27}$, como ya se había hecho años antes con la aceptación para este fin del legado del clérigo Matías José Caballero, en $1722^{28}$. Sin embargo, a pesar de las interrupciones y retrasos en su ejecución, lo que nos interesa señalar es que al menos desde 1705 consta, a través del testimonio del visitador Juan Bejarano Muñoz, que el inconcluso retablo estaba ya presidido por la imagen de Nuestra Señora de la Paz (imágenes 4 y 5), obra de talla que, adaptándose a los cambios de gusto y sensibilidad de la estética barroca, también se vestía, lo cual, como vimos en San Lucas, obligó a desarrollar un ámbito espacial mayor, capaz de albergar la imagen holgadamente ${ }^{29}$. Pero los paralelismos con San Lucas no acabarían ahí, pues la imagen del titular del templo también quedaría relegada a una hornacina sobre el camarín de la Virgen, ubicación que tardó en ocupar, pese a estar previsto de este modo desde la traza, debido a las constantes interrupciones de los trabajos ${ }^{30}$. Éstos concluyeron, una vez más como en el templo de la collación vecina, con el refresco pictórico

\footnotetext{
${ }^{26}$ «El secretario me remitió traslado de una carta de los beneficiados de la parrochia del Señor San Juan de los Cavalleros en que pretendían que Vuestra Eminencia mandase que la fábrica de dicha Yglesia ayudase con dozientos Ducados para acabar de perfeccionar un retablo que esta comenzado a poner en el altar mayor de dicha yglesia a costa de los hermanos de nuestra Señora de la Paz que se yntenta colocar en dicho altar y retablo. Y aunque tendrá mucha más costa que dichos 200 ducados se contentan dichos hermanos con esta ayuda de costa que dizen decrettó Vuestra Eminencia abra cinco años que se diesen. Y prettendiendo conmigo que se librasen. Pedí dicho decreto que dizen lo an perdido. Y negando yo por este motivo la providencia a su petición recurrieron a Vuestra Eminencia sobre que devo dezir en cumplimiento del orden de Vuestra Eminencia que es cierto que será de mucha desencia para dicha yglesia dicho retablo por estar muy desadornada pero también es cierto que la fábrica de dicha Yglesia es sumamente pobre y que su caudal alcanza escasamente para el gasto ordinario y paga de los ministros. Que es quanto se me ofrese partiçipar a Vuestra Eminencia pidiendo a Nuestro Señor la grandeza de su Persona dilatados años». [Carta de] Pedro Fernández de Zurita al Cardenal Arias sobre asuntos relativos a la visita. 11 de diciembre de 1715. AGAS, Sección II, Serie visitas, legajo 1454, s./f.

27 «Que por quanto está principiado retablo en el altar maior de esta yglesia y se nos ha informado a ofrecido el cuerpo de Hermanos de Nuestra Señora de la Paz titular de el por medio de sus hermanos maiores y mayordomo se dedicaran a contribuir con el costo del maestro y oficial que le están executando los meses que pudieren juntar para ello con la calidad de que esta fábrica contribuía alternatibamente para que tenga efecto la execución de dicho retablo, mandamos que el mayordomo nuebamente nombrado reconosiendo se aplican los hermanos mayores a executar lo que an ofresido contribuía según la posibilidad de esta fábrica con intervención de los curas y beneficiados de esta yglesia teniendo presente la corta renta que tiene para su manutención y encargamos a los dichos curas y beneficiados para que se consiga con maior brevedad exorten y pidan a los feligreses de esta collación que cada uno contribuía con la limosna que pudiere». Mandatos de la visita pastoral... op. cit., 1728. AGAS, Sección II, Serie visitas, legajo 1369, ff. 449r-449v.

${ }^{28}$ MORENO ARANA, José Manuel: El retablo... op. cit., pp. 216-220.

29 «Es esta parrochial de solo una nave y bóveda de cantería grande y con mucha luz y su altar maior tiene retablo nuevo que solo está hasta la mitad y en el cuerpo principal del está colocada una ymagen de nuestra señora de la Pax de cuerpo entero de escultura y también se viste». Resulta y mandatos... op. cit., 1705. AGAS, Sección II, Serie visitas, legajo 1348, s/f.

30 «Y por no proseguir el retablo no está en el la ymagen del santo Evangelista que según el diseño a de estar en el cuerpo y nicho principal de dicho retablo». Ibidem.
} 
de toda la cabecera, que fue «estofada» para la gran fiesta de inauguración del retablo que tuvo lugar el ocho de enero de $1780^{31}$. Ni el retablo, retirado del presbiterio en el siglo XIX y con importantes mutilaciones; ni la cabecera, despojada entonces de sus aditamentos barrocos e inmediatamente neomedievalizada; ni la propia imagen de la Virgen de la Paz, también transformada por completo, nos permiten intuir la pujanza que alcanzó su devoción ${ }^{32}$.

\section{Imagen 4}

\section{Retablo mayor de San Juan de los Caballeros}

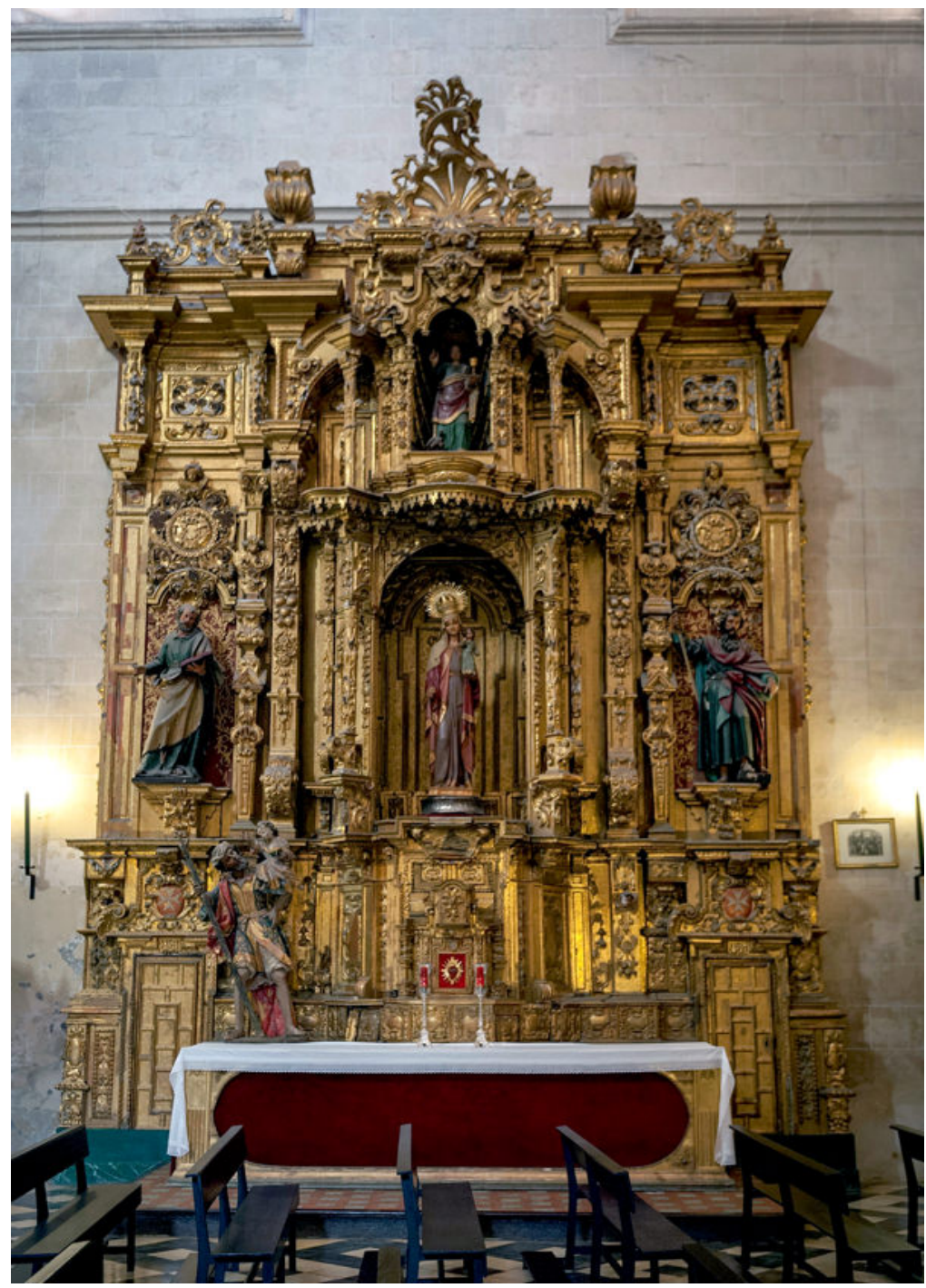

Francisco Antonio de Soto y otros, 1698-1733

31 MORENO ARANA, José Manuel: El retablo... op. cit., p. 217.

32 ÁLVAREZ LUNA, María de los Ángeles, GUERRERO VEGA, José María y ROMERO BEJARANO, Manuel: La intervención en el patrimonio. El caso de las iglesias jerezanas (1850-2000), Jerez de la Frontera, Ayuntamiento de Jerez, 2003, pp. 106-111. 


\section{Imagen 5}

\section{Retablo mayor de San Juan de los Caballeros. Pormenor del camarín con la imagen de Ntra. Sra. de la Paz}

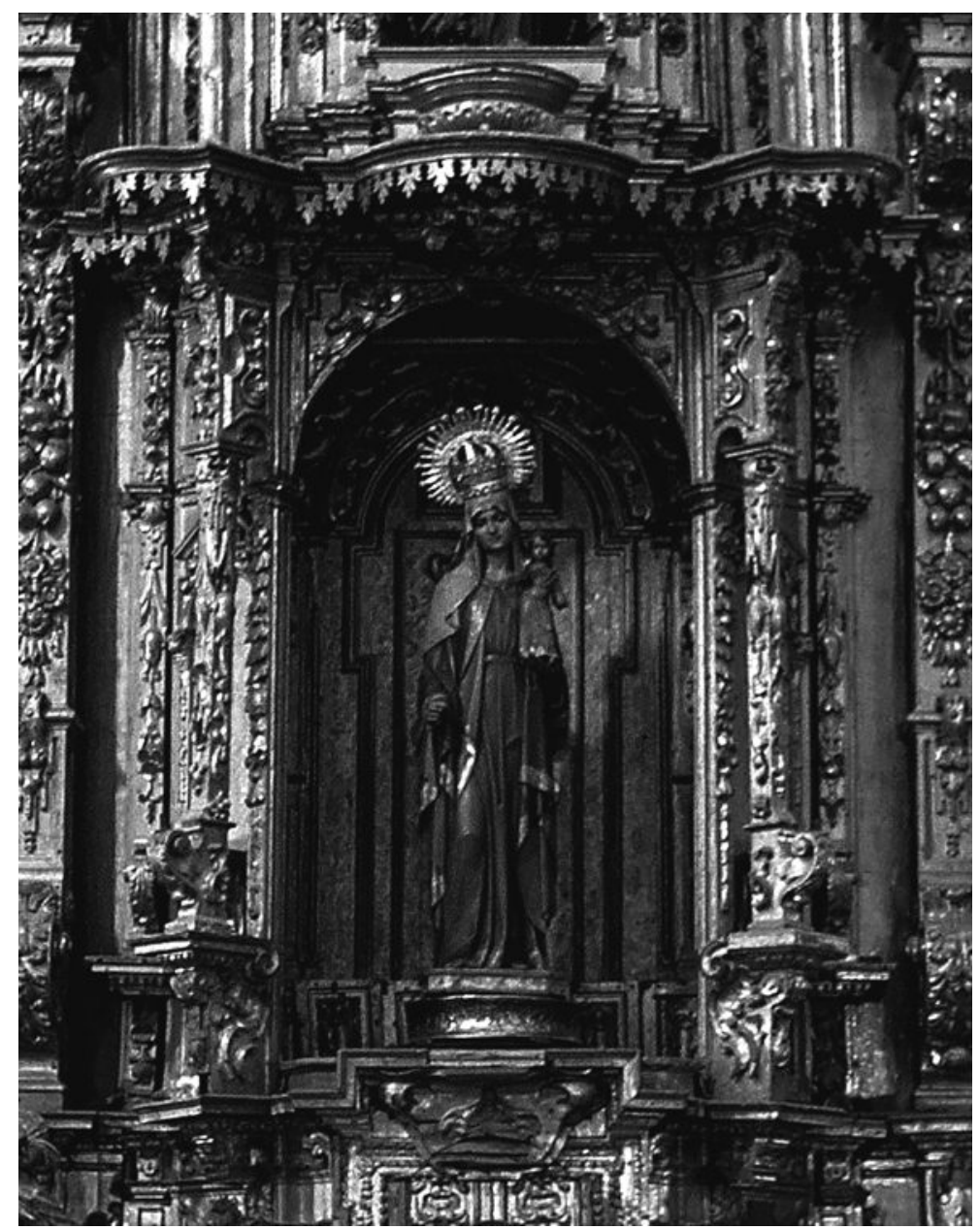

Nicolás de León, S. XVI.

En San Marcos se encontraba otra imagen de la Virgen de la Paz, advocación que hunde sus raíces, al igual que su homónima de San Juan, en históricos acontecimientos locales de finales de la Edad Media, al haberse celebrado ante ella, en 1462 y 1467, las juntas de notables presididas por el duque de Medina Sidonia que trataron de acabar con los conflictos banderizos de la nobleza jerezana ${ }^{33}$. El padre Rallón detalla que estaba ubicada entonces la imagen en el altar de la capilla funeraria de don Pedro González de Mendoza, donde excitaba el fervor de la feligresía, que le dedicaba una misa solemne con octava en el mes de

\footnotetext{
${ }^{33}$ RALLÓN, Fray Esteban: Historia de la ciudad... op. cit., t. IV, p. 13; MESA GINETE, Francisco de: Historia sagrada ... op. cit., t. II, p. 153; POMAR RODIL, Pablo J. y MARISCAL RODRÍGUEZ, Miguel Á.: Jerez: Guía artística y monumental, Madrid, Sílex, 2004, p. 50.
} 
septiembre, acompañada de fiestas y fuegos de $\operatorname{artificio~}^{34}$. A este testimonio cabe añadir el del visitador Gonzalo de Mier, quien en 1673, además de hacerse eco de la gran devoción que en efecto despertaba la imagen, añade cómo todas las noches se le rezaba el rosario y se tenía ante ella una hora de oración menta ${ }^{35}$. No es de extrañar, por tanto, que se aprovechase la coyuntura que suponía la completa renovación del retablo mayor a partir de 1698, en la que, aunque se conservaron sus tablas pictóricas del siglo XVI, toda la máquina lignaria fue hecha de nuevo por el entallador José Rey, para entronizar en él a la Virgen de la Paz ${ }^{36}$, que a partir de aquel momento quedó presidiendo el templo parroquial hasta finales del siglo $\mathrm{XVIII}^{37}$. Cabe especular que las deplorables condiciones en que se encontraba de la capilla de los González de Mendoza coadyuvaran a la hora de decidir el traslado de la imagen al altar mayor, pero en modo alguno éste se hubiese llevado a cabo de no mediar la extraordinaria devoción descrita ${ }^{38}$.

Significativamente, se comprueba que el fervor inmaculista y mariano, que ya advertimos como marco de estas intervenciones que hemos ido desgranando, logró materializarse en la renovación de viejas imágenes de la Virgen, que, por su propia antigüedad y su desfasada estética medieval o altomoderna, despertaban un extraordinario ardor espiritual en los fieles, que las debieron de percibir como una suerte de piadosos y atemporales iconos, un fenómeno en cierto modo semejante al de las imágenes de Cristo crucificado que estuvieron ubicadas en las vigas que solemnizaban el ingreso al presbiterio

\footnotetext{
34 «La más célebre de estas capillas es la de don Pedro González de Mendoza, por estar en ella la milagrosa imagen de Nuestra Señora de la Paz, cuyo nombre se le dio por haberse concordado en presencia, cuando estaba en la capilla de los Nateras, nuestros caballeros, y jurados las paces olvidando los enconos y enemistades antiguas. Hácesele todos los años una solemnísima octava con todo regocijo, fiestas y fuegos, con misa solemne, música y sermón por el mes de septiembre» RALLÓN, Fray Esteban: Historia de la ciudad... op. cit., t. IV, p. 134. 35 «En el altar comulgatorio esta una imagen de Nuestra Señora de la Paz, de talla, donde todas las noches se reza el rosario por el cura y se tiene una hora de oración mental y, asimismo, se reza el rosario en todas las iglesias de esta ciudad por los curas, y se llama cerca de la oración antes media hora a campana tañida». Al margen, comprendiendo este párrafo y el siguiente (dedicado al Cristo de la Viga): «imágenes de mucha devoción». Visita de las parroquias... op. cit., 1673. AGAS, Sección II, visitas, legajo 1443, s./f.

${ }^{36}$ Hipólito Sancho sugirió la posibilidad, tras el estudio de un viejo inventario parroquial de San Marcos, de que la Virgen de la Paz ya hubiese presidido con anterioridad el retablo mayor, al menos hasta 1604, posibilidad sobre la que preferimos tomar una prudente distancia. SANCHO DE SOPRANIS, Hipólito: «El retablo de la capilla mayor de San Marcos, de Jerez. Notas y referencias documentales inéditas», Archivo Hispalense, 17 (1952), pp. 145-146, n. 5.

${ }^{37} \mathrm{El}$ arzobispo don Alonso Marcos de Llanes y Argüelles emitió un decreto en noviembre de 1794 ordenando que en la hornacina de la Virgen de la Paz pasase a estar ocupada por un nuevo sagrario y manifestador, que se concluirían en 1800. MORENO ARANA, José Manuel: El retablo... op. cit., pp. 526-527.

38 Otro dato que pone de relieve la devoción a la Virgen de la Paz, más allá de lo descrito por Rallón y los visitadores, será el hecho de que los cofrades de su hermandad la sacasen en procesión, para lo cual encargaron unas andas al tallista Juan González de Herrera en 1694; En un inventario de bienes de la parroquia de 1849 se mencionan unas andas de madera dorada que acaso pudieran estas mismas. MORENO ARANA, José Manuel: El retablo... op. cit., p. 198; Inventario de la parroquia de San Marcos ordenado por el visitador Gregorio López, 1849, AGAS, Sección IV, Serie 13, legajo 1421, s/f.
} 
de estos mismos templos ${ }^{39}$. En el caso de las efigies marianas, los santos titulares de las parroquias jerezanas quedaron reubicados en los cuerpos superiores de los retablos, lo que les permitía en cierto modo mantener visualmente la presidencia de estos altares, la cual, con la incorporación de los sagrarios en el siglo XVI, y de las imágenes de la Virgen en el XVII, había quedado sin duda relegada y desdibujada.

Durante el siglo XVIII, a pesar de que el caudal de noticias disminuye, podemos afirmar que la piedad mariana en Jerez, lejos de debilitarse, prosiguió floreciente. Un análisis en paralelo de cuanto acontecía en los templos de los religiosos de la ciudad parece probarlo, al tiempo que pone de manifiesto cómo la devoción a la Inmaculada resultaba decisiva a la hora de componer los programas iconográficos de los nuevos retablos que en este siglo renovarían muchas de sus cabeceras, como sería el caso del convento de San Francisco ${ }^{40}$, en 1707, y de la Veracruz ${ }^{41}$, en 1730, entre otros. Cabe admitir que estos precedentes hubiesen influido ya a mediados de siglo en la iconografía del desaparecido retablo mayor de la parroquia de Santiago, obra barroca de Francisco Camacho de Mendoza, que al parecer contó con una imagen de la Inmaculada en lo que la documentación denomina como «segundo trono», probablemente un elevado camarín ubicado en su calle central ${ }^{42}$. Pero sin duda, la cristalización de todo este movimiento llegaría durante el reinado de Carlos III, de tan honda devoción concepcionista, quien, entre 1760 y 1767, obtendría de Clemente XIII el patronazgo de la Inmaculada sobre España y otros notables privilegios litúrgicos vinculados a esta pía creencia mariana ${ }^{43}$, lo que en Jerez se festejó con solemnes funciones para las que

\footnotetext{
39 Sobre los Crucificados bajomedievales que presidieron la colegiata y parroquias de Jerez vid. POMAR RODIL, Pablo J:: «Entre la liturgia medieval y la piedad contrarreformista. La imagen de Cristo crucificado en Jerez de la Frontera», en J. E. Jiménez López de Eguileta y P. J. Pomar Rodil (coords.): Limes Fidei. 750 años de cristianismo en Jerez, Jerez de la Frontera, Diócesis de Asidonia-Jerez, 2014, pp. 146-163.

40 MESA GINETE, Francisco de: Historia Sagrada ... op. cit., t. II, p. 490.

41 ANTÓN PORTILLO, Jesús y JÁCOME GONZÁLEZ, José: «La Inmaculada Concepción del antiguo convento de la Vera Cruz, de Jerez de la Frontera», Revista de Historia de Jerez, 16-17 (2014), pp. 135-150

42 SANCHO DE SOPRANIS, Hipólito: «Papeletas para una serie de artistas regionales (Segunda serie)», Guión, 24 (1936), p. 19; ALONSO DE LA SIERRA FERNÁNDEZ, Lorenzo y HERRERA GARCÍA, Francisco Javier: «Aproximación a la escultura jerezana del siglo XVIII: Francisco Camacho de Mendoza», Atrio, 5 (1993), pp.34-35 y 46-47; MORENO ARANA, José Manuel: El retablo... op. cit., p. 268.

${ }^{43}$ El ocho de noviembre de 1760, Clemente XIII concedió, a petición Carlos III, el patronazgo de la Inmaculada sobre España y las Indias, sin detrimento del ya ejercido por el apóstol Santiago. El rey, mediante un decreto firmado en El Pardo el dieciséis de enero de 1761 sancionó este patronazgo concedido por el papa. Este último, también a petición del monarca, extendió y aplicó el oficio y misa de la Inmaculada Concepción, como doble de primera clase con octava, a todo el clero regular y secular. En 1767, una vez más a instancia de Carlos III, el papa impuso al clero la obligación de rezar el oficio propio de la Inmaculada todos los sábados que no fuesen fiesta doble o semidoble, exceptuando los de Adviento, Cuaresma, témporas y vigilias. Igualmente concedió el pontífice, siempre a súplica del rey, que en las letanías después de «Mater intemerata» se añadiese «Materinmaculata» en todos los reinos de España y las Indias. Novísima recopilación de las

leyes de España. Imprenta de Sancha. Madrid, 1805, t. I, pp. 8-10, nn. 14-16; POMAR RODIL, Pablo J.: «"El medio de adquirir feligreses". Liturgia parroquial y espacio arquitectónico en la iglesia de San Mateo de Jerez
} 
incluso se erigió en 1761 un efímero arco triunfal en la calle Medina ${ }^{44}$. Entre estas muestras de entusiasmo inmaculista cabría incluir, como una suerte de respuesta plástica perdurable, la colocación en el nuevo retablo (imagen 6) de la parroquia de San Mateo, construido por Andrés Benítez justamente entre 1766 y 1768, de otra imagen de la Inmaculada Concepción, aparatosa y monumental, que ha sido relacionada con la producción del escultor Francisco Gavilán $^{45}$. A ésta quedó reservado el gran camarín (imagen 7) que, por su dimensión y centralidad, reclama cualquier mirada que se dirija al retablo ${ }^{46}$. En éste, una vez más la imagen del titular del templo, el evangelista San Mateo, queda desplazada a un discreto nicho ubicado entre el mencionado camarín y el crucificado que corona la máquina, que eran las representaciones escultóricas que habían acaparado la calle central del precedente retablo pictórico $^{47}$. Finalmente también, cuando en 1778 los capitulares jerezanos encargaron al genovés Jacome Vacaro la ejecución del retablo o «cogollo» que a modo de tabernáculo habría de adornar el altar mayor de la flamante iglesia colegial que se inauguraría aquel año, una vez más el titular del templo, el Divino Salvador, sería elevado al ático con la intención de liberar el espacio principal y acoger en él una escultura de la Inmaculada, continuando así con la tradición concepcionista que el cabildo arrastraba desde la centuria precedente ${ }^{48}$.

de la Frontera», en J. E. Jiménez López de Eguileta (coord.): La parroquia de San Mateo de Jerez de la Frontera: historia, arte y arquitectura, Murcia, Universidad de Murcia, 2018, p. 514, n. 28.

44 TRILLO Y BORBÓN, Juan de: Libro en donde están apuntadas todas las novedades acaecidas en esta ciudad de Xerez de la Frontera desde el año 1753 y algunas otras que han ocurrido fuera de ella, Jerez de la Frontera, Melchor García Ruiz, 1890, p. 12; PÉREZ REGORDÁN, Manuel: El jerezano Andrés Benitezy su concepto del rococó, Jerez de la Frontera, CEHJ, 1995, pp. 43-45.

45 PINERO, Javier: «La iglesia de San Mateo», El Guadalete, 10981 (10-I-1892), p. 1; PÉREZ REGORDÁN, Manuel: El jerezano... op. cit., pp. 70-72 y 134-136.

${ }^{46}$ Esta escultura viene recogida en algunos inventarios decimonónicos como «Asunción», sin embargo, debe tratarse de un mero error de identificación repetido en el tiempo, dado que, como ha sido puesto de relieve, reproduce fielmente un modelo de Inmaculada de progenie compositiva netamente murillesca. MORENO ARANA, José Manuel: El retablo... op. cit., p. 514-515; MORENO ARANA, José Manuel: «La escultura en el retablo jerezano del siglo XVIII. Autores y obras», Laboratorio de Arte, 26 (2014), p. 243; MORENO ARANA, José Manuel: «Retablos y esculturas barrocos de la iglesia de San Mateo», en J. E. Jiménez López de Eguileta (coord.): La parroquia de San Mateo de Jerez de la Frontera: historia, arte y arquitectura, Murcia, Universidad de Murcia, 2018 , p. 484 , n. 50.

${ }^{47}$ Las descripciones del retablo preexistente parecen descartar que contase con imagen mariana alguna. Sí, en cambio, refieren la presencia de una escultura de San Mateo sedente que aún se conserva en la sacristía. Así, el visitador Gonzalo de Mier y Barreda señala en 1673 que «el altar mayor se compone de diferentes cuadros unidos con marcos dorados a los lados y en el medio está en forma de nicho la imagen del titular, y en lo demás alto se remata con un crucifijo muy antiguo y devotísimo» (Visita de las parroquias... op. cit., 1673. AGAS, Sección II, visitas, legajo 1443, s./f); Parecida retrato hará décadas más tarde, en 1705, otro visitador, en este caso Juan Bejarano Muñoz, quien se detiene en describir que «el retablo maior está adornado con retablo de pinturas de lienzo con marcos dorados y en el principal nicho está el santo evangelista que es de cuerpo entero de escultura» (Resulta y mandatos... op. cit., 1705. AGAS, Sección II, Serie visitas, legajo 1348, s/f); Una notable actualización ordenada de cuanto se conoce de este desaparecido retablo en CARAMAZANA MALIA, David: «El primitivo retablo mayor de San Mateo de Jerez de la Frontera y la escultura renacentista en madera de su parroquia», en J. E. Jiménez López de Eguileta (coord.): La parroquia de San Mateo de Jerez de la Frontera: historia, arte y arquitectura, Murcia, Universidad de Murcia, 2018, pp. 440-459.

48 POMAR RODIL, Pablo J.: «Divino Salvador», en J. E. Jiménez López de Eguileta y P. J. Pomar Rodil (coords.): Limes Fidei. 750 años de Cristianismo en Jerez, Jerez de la Frontera, Diócesis de Asidonia-Jerez, 2014, p. 310. 


\section{Imagen 6}

\section{Retablo Mayor de San Mateo}

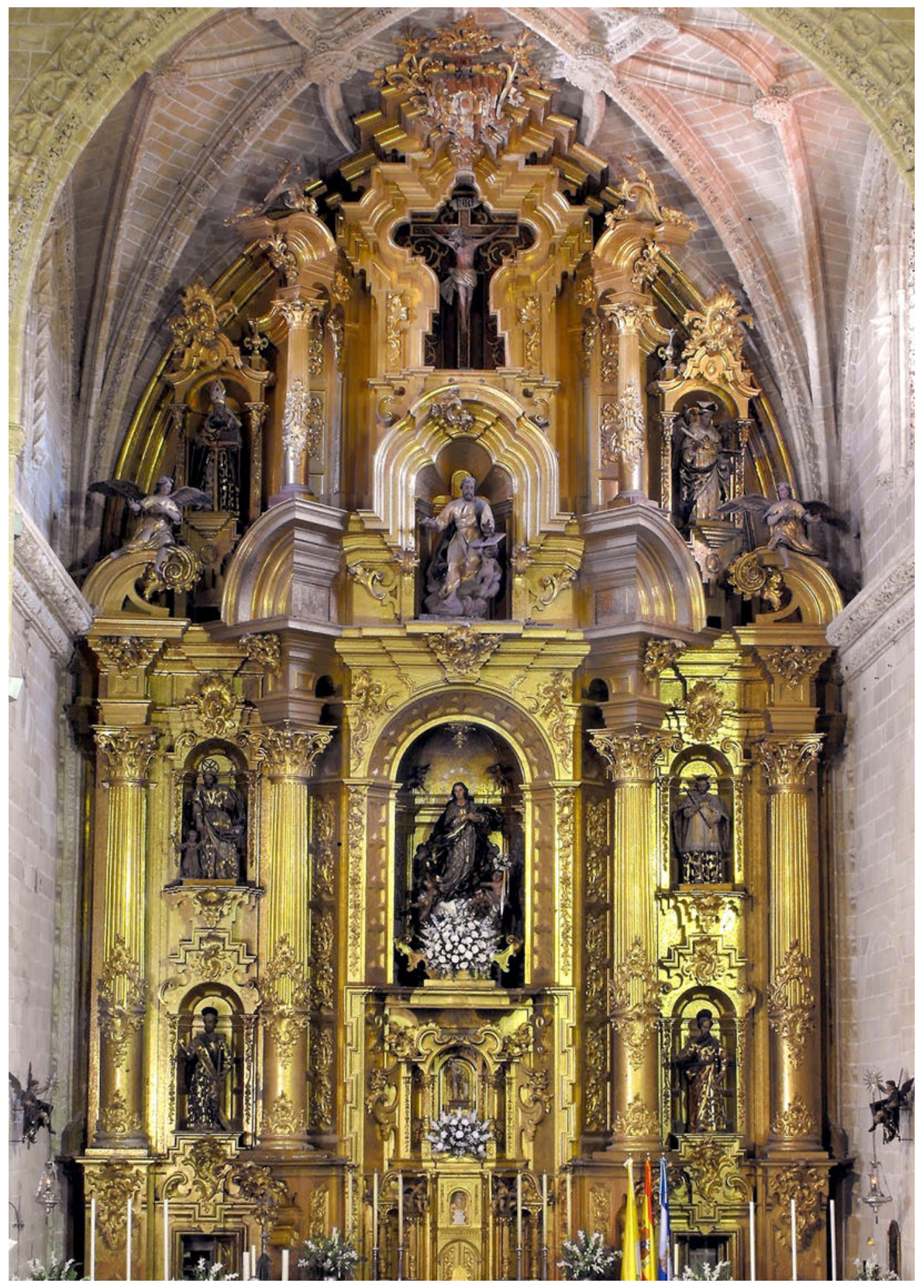

Andrés Benítez, 1766-1768 


\section{Imagen 7}

Retablo mayor de San Mateo. Pormenor del camarín con la imagen de la Inmaculada

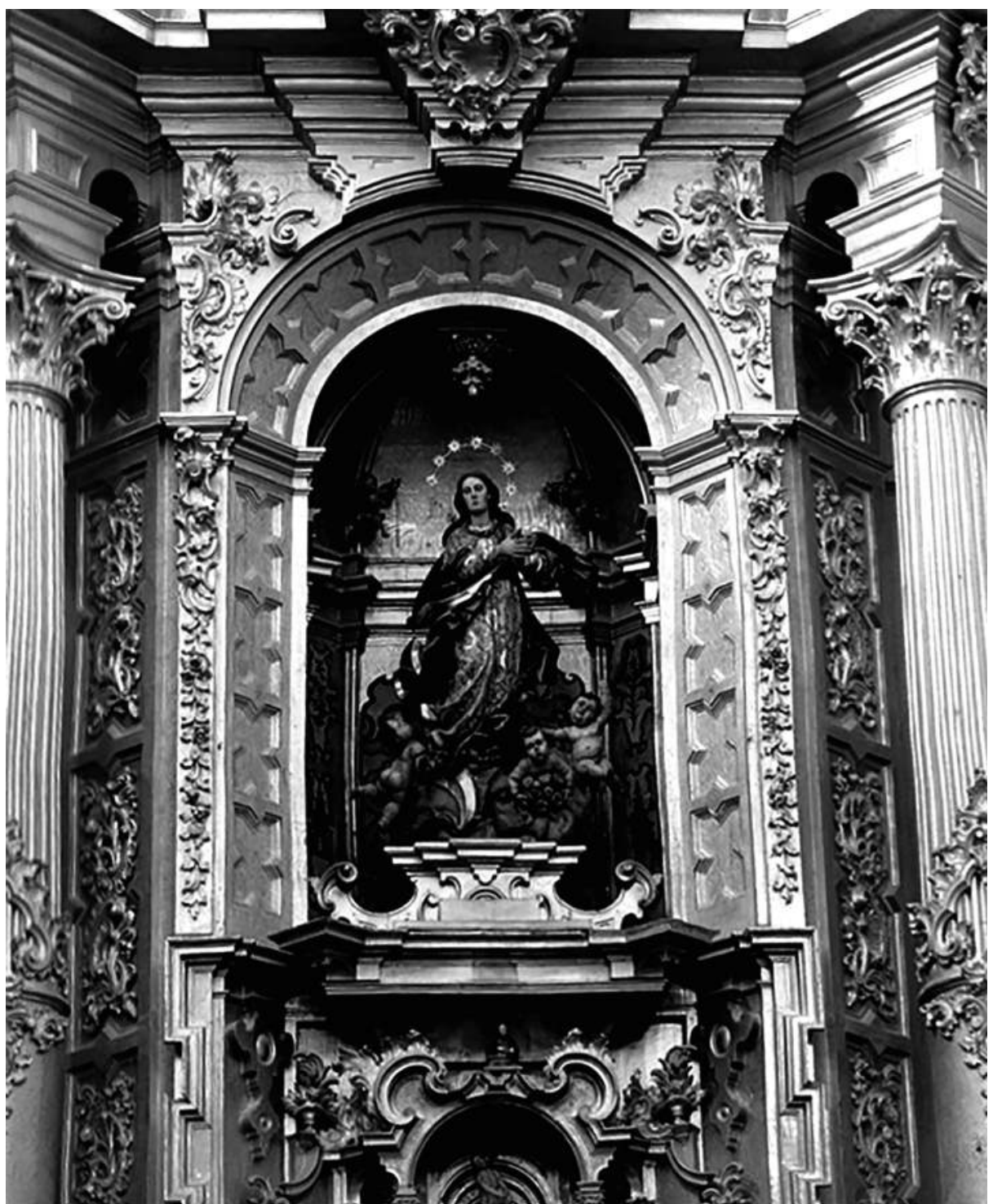

Francisco Gavilán (atrib.), 1767 ca

$\mathrm{Si}$, al margen de la rica concentración documental con la que hemos pretendido apuntalar las ideas presentadas, recapitulamos y nos centramos en estas últimas, podemos inicialmente identificar de forma nítida los distintos agentes implicados en este proceso. A saber, la inicial transformación durante el siglo XVII de la calle central de los antiguos retablos mayores para acoger en ella una imagen de la Virgen, que, pese a ser frecuentemente de talla completa, comienza a ser vestida con mantos y velos, lo que condiciona el ámbito espacial que las acoge, que necesariamente ha de ser más amplio, influyendo esto en la 
aparición de los camarines. Necesariamente, el santo titular del templo, que hasta entonces había presidido el retablo desde la hornacina central ubicada en aquel espacio, sería reasentado en un nuevo nicho a más altura, entorpeciéndose así su recepción visual por parte de los fieles, que paulatinamente se iban desentendiendo de su culto, al tiempo que crecía el dispensado a la Virgen. Finalmente, los nuevos retablos barrocos que tapizarían de talla dorada las viejas cabeceras góticas de los templos jerezanos serían trazados siguiendo ya la nueva composición. A la construcción de estas complicadas máquinas, además, contribuirían significativamente las hermandades que rendían culto a las mencionadas imágenes marianas que ahora presidían los templos. Si nos detenemos a considerar la elocuencia de toda esta evolución, encontramos que, en estos retablos mayores, como ajustada consecuencia plástica que son de unas ideas religiosas en desarrollo -en concreto las de la ausencia de pecado original en la Virgen María desde el momento de su concepción-, los propios fieles habían alcanzado a entrever el progreso teológico subyacente ${ }^{49}$. El retablo no es, desde luego, el único soporte plástico donde se puede identificar la fuerza del fervor mariano como motor de importantes transformaciones de los programas iconográficos. Basta recordar las alteraciones que, para introducir a la Inmaculada, sufrieron en la catedral de Sevilla desde espacios señeros, como su propia sala capitular, hasta la gran custodia del Corpus, la primera a manos de Bartolomé Esteban Murillo en 1667, y al año siguiente la segunda, trabajo que corrió a cargo del orfebre Juan de Segura ${ }^{50}$. Pero, a pesar de todo, resulta ostensible la asombrosa capacidad del retablo para acoger, con extraordinaria versatilidad, la plasmación material y artística de aquellas cuestiones de fe para cuya aparatosa exposición habían sido concebidos. La muestra aquí escogida para fundamentarlo, compuesta por las ocho parroquias jerezanas con su colegiata al frente, en la que tan sólo una, la de San Miguel ${ }^{51}$, no se ajusta al patrón descrito, parece confirmarlo.

\footnotetext{
${ }^{49}$ El caso mariano escogido para este trabajo no habría sido ni mucho menos único. Los retablos permiten leer, a través de las alteraciones sufridas durante su historia, desde otras fluctuaciones devocionales -claramente perceptibles serán los cambios que tantas veces presenta su imaginería respecto a la prevista en el programa iconográfico original- hasta buena parte de la historia del culto eucarístico católico. Esto último es posible especialmente a través de la identificación de las intervenciones sufridas a partir de los años finales del siglo XVI para acoger tanto los sagrarios de la reserva eucarística que habría de presidir los templos, como también, aunque por lo general más tardíamente, manifestadores para la exposición del Santísimo Sacramento. MARTíN GONZÁLEZ, Juan José: «Sagrario y manifestador en el retablo barroco español», Imafronte, 12 (1998), pp. 2730.

50 Deseo mostrar mi agradecimiento al profesor Álvaro Recio Mir, que me hizo notar este significativo paralelismo. RECIO MIR, Álvaro: "Sacrum Senatvm". Las estancias capitulares de la Catedral de Sevilla, Sevilla, Universidad de Sevilla, 1999, pp. 184-186; SANZ SERRANO, María Jesús: Juan de Arfe y Villafañe y la custodia de la Catedral de Sevilla, Sevilla, Universidad de Sevilla, 2006, pp. 106-111.

${ }^{51}$ El retablo mayor de la iglesia parroquial de San Miguel, por sus características excepcionales, pero más aún por la conciencia de obra de arte excepcional que le acompañó desde el momento de su ejecución y también por la memoria de su autoría montañesina siempre presente, no parecía una pieza fácilmente alterable. Además, la gran devoción mariana de la parroquia, la Virgen del Socorro, imagen de piedra policromada que también se vestía, contaba con hermandad, salía en procesión, etc., presidía la espaciosa nave de la epístola, mayor que la central de otras parroquias. Aun así, parte de los aspectos analizados en el presente trabajo podrían ponerse también en relación con sus excepcionales retablos perdidos y aún con el presente, sobre los que existe una documentación abundantísima.
} 